Ethiopian Journal of Environmental Studies \& Management 7 Suppl.: 720 - 730, 2014.

ISSN:1998-0507

doi: http://dx.doi.org/10.4314/ejesm.v7i1.3S

Submitted: June17, 2014

Accepted: November 03, 2014

\title{
ROAD CONSTRUCTION AND GULLY DEVELOPMENT IN HADERO TUNTO - DURGI ROAD PROJECT, SOUTHERN ETHIOPIA
}

\author{
LIUELSEGAD BELAYNEH' ${ }^{1}$ *AMARE BANTIDER ${ }^{2}$ AND AWDENEGEST MOGES 3 \\ ${ }^{1}$ Department of Natural Resource Management, Arba Minch University, Arba Minch, Ethiopia \\ ${ }^{2}$ Center for Food Security Studies, College of Development Studies, Addis Ababa University, \\ P.O. Box 1176, Addis Ababa, Ethiopia \\ ${ }^{3}$ School of Biosystems and Environmental Engineering, Hawassa University, P.O. Box 5, \\ Hawassa, Ethiopia
}

\begin{abstract}
Poor drainage systems in roads are among causes of gully erosion and are common in Ethiopia. A study was conducted to assess gully development and perception of farmers on gully erosion problems along Hadero Tunto-Durgi road project, south Ethiopia. The road was built between 2006 and 2008. The study area covered 572 ha of Ereramo, Satame and Koka road sections. Field observations, gully measurement, and household survey were used to generate the necessary data. The study reveals that 20 new gullies have been created down slope of the investigated road segments. Their development is found to be associated mainly with culverts and roadside ditches. The soil loss rate by gully is estimated at $12.86 t \mathrm{ha}^{-1} \mathrm{y}^{-1}$ and the total damaged area estimated at $16,109 \mathrm{~m}^{2}$. The gully density $9.36 \mathrm{~m} / \mathrm{ha}$ implies moderately to severely degraded situation. The house hold survey shows that about $96 \%$ of sample respondents have experienced problems of gully erosion. They explained that gullies became obstruction of tillage operation, cause for loss of soil and yield reduction, and restrict animal and human movement. The study concludes that if appropriate interventions are not carried out in the area, the rate of gully erosion will increase and reversing the process will be difficult.
\end{abstract}

Key Words: Gully erosion; road construction; farmers' perception; Southern Ethiopia

\section{Introduction}

Adequate road infrastructure eases access and is very important for socio-economic development. In Ethiopia and in developing countries in general development of rural infrastructure is a major priority for reducing rural poverty (World Bank, 1994). In Ethiopia, as pro-poor sector, significant budget is allocated to road construction, which is comparable to that of health and water. However, necessary precautions must be taken during construction of different infrastructure like roads not to endanger the

*Corresponding Author: Amare Bantider

Email: amare_zerfe@yahoo.com environment. Gully development is one type of land degradation that is caused by inappropriate infrastructural constructions. In this regard, Pathak et al. (2006) stated that inadequate drainage systems for roads such as small number of culverts and insufficient capacity of road ditches are some of the causes of gulling.

According to Peter and John (2002) road surfaces cause rill and sheet erosion, whereas, inappropriate road culverts and ditches are major causes of gully erosion risk. Culverts are required in order to allow natural 
Road Construction and Gully Development in Hadero Tunto-Durgi.................BELAYNEH et al.

streams to cross the road, and discharge surface water from drains and the areas adjacent to the road. It is recommended that, for unpaved roads, ditches must be lined with stone and grass; and for paved or asphalt road, ditches should be constructed from cement and concrete to control erosion. However unlined ditches are subject to erosion leading to gully formation in many instances. Moeyersons (1991) monitored and analyzed progressive gully formation after road building in Rwanda. Ogbaghebriel and Brancaccio (1993) present examples of gullies induced by roads on pediments in the Ethiopian Highlands. Montgomery (1994) found that the main causes of gulling after road building are overland flow concentration by the establishment of artificial drains and increased catchment area. While road constructions are given priority and considerable finance is allotted in Ethiopia, it is common to observe i) newly constructed roads causing damage to the surrounding and ii) built roads being damaged soon after their construction. These situations result in worsening the life of farmers, creating increased maintenance cost, and giving poor road services. However, there is no substantiated and empirical evidence of such a case particularly in the southern Ethiopia.

The objectives of this study were, therefore, to analyze gully morphology and its development; to assess and quantify erosion damages and associated problems; and to assess perception of farmers on the developed gullies in the study area.

\section{Materials and Methods Study Area}

The study area is located in Southern Nations, Nationalities and Peoples Regional State, Ethiopia. The studied road is an all weathered road that covers $32 \mathrm{kms}$ with 10 $\mathrm{m}$ width, and links two Woredas, namely Hadero Tunto and Tembaro (Figure 1). It is approximately $380-412 \mathrm{kms}$ away from Addis Ababa. The study was specifically carried out on 260 meters band (strip) of area centering the road. This road project took two years to complete starting in 2006 and completed in 2008.

The climate of Hadero Tunto and Tembaro woredas is characterized by unimodal rainfall distribution that extends from April to October. Annual rain fall in the area ranges from $935 \mathrm{~mm}$ to $1877 \mathrm{~mm}$ and the mean monthly temperature ranges from $9.5^{\circ} \mathrm{c}$ to $30^{\circ} \mathrm{C}$ (Hawassa Meteorology Office, 2013).

The common soil of the study area is alfisols (nitisols) (BOFED, 2004), soils with a base saturation of $50 \%$ or more through the argilic B-horizons within $125 \mathrm{~cm}$ of the surface (Mesfin, 1998). Alfisols are among the best agricultural soils with clay to clayloam texture, imperfect drainage and effective depth of greater than $150 \mathrm{~cm}$ with the $\mathrm{pH}$ value from 5.5 to 6.7 .

The major land use types in the area are: arable land, natural forest, forest plantations, grazing land, and human made structures: such as roads and villages. The main cereal crops common in the area are teff (Eragrostis teff), maize (Zea mays L.) and enset (Ensette ventricossum). Fruits and vegetables are also common. 


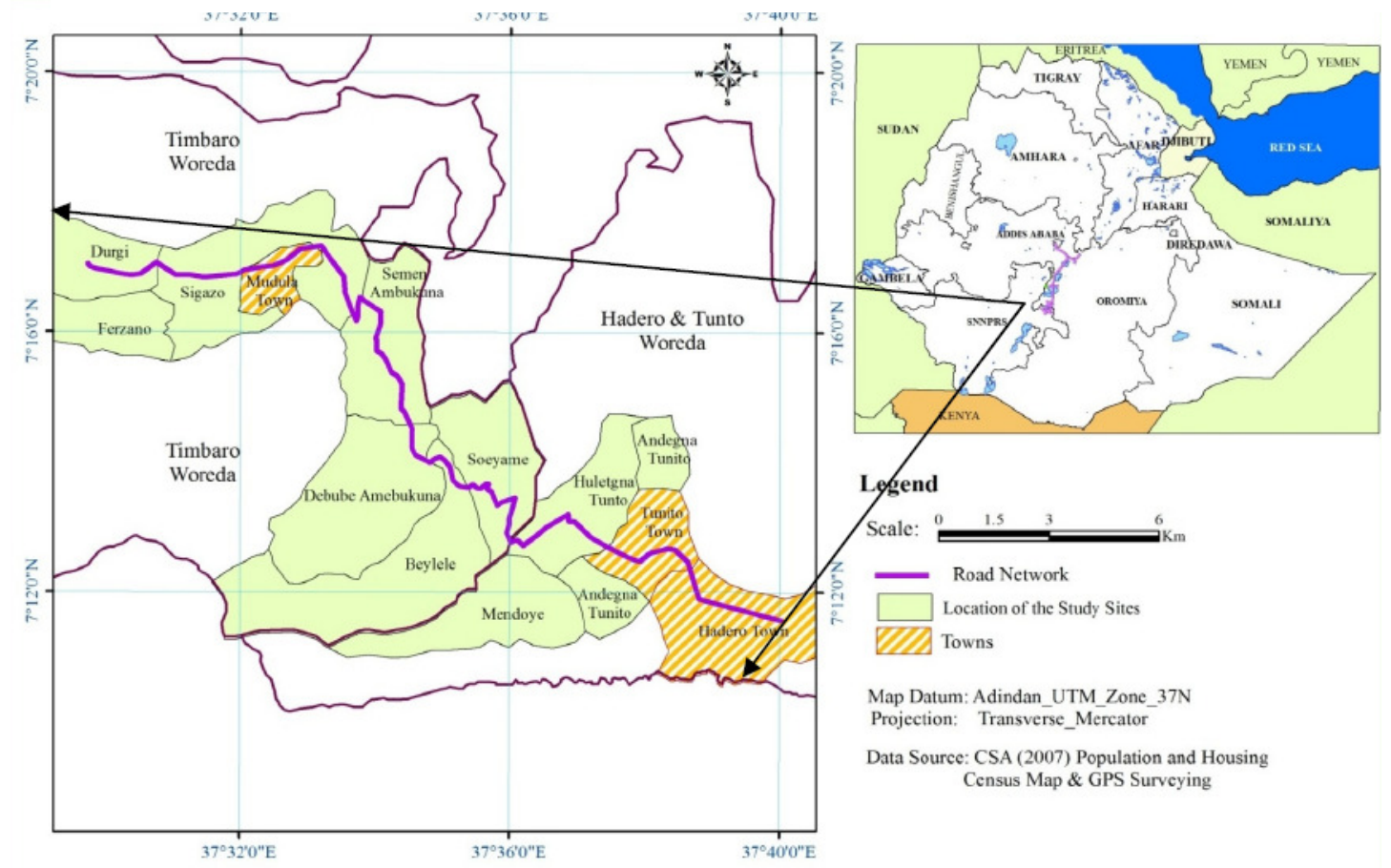

Figure 1: Location of the study area

\section{The Study Design}

The entire road of the study area was examined for drainage lines, river crossings, land-use and soil types. GPS readings of the whole length of the road were taken along both sides. The road crosses five local streams namely, Sana, Ereramo, Satame, Koka, and Lamo. To select representative sample sites from the road, road sections draining to the five streams were identified. By identifying water divide lines using GPS readings, the road was divided in to five sections. The identified road sections and their altitude range are depicted in Table 1.

Table 1: Names of road sections identified for the study

\begin{tabular}{lll}
\hline No. & Name of road section & $\begin{array}{l}\text { Altitudinal } \\
\text { range (m.a.s.l) }\end{array}$ \\
\hline 1 & Sana road section & $1547-1677$ \\
2 & Ereramo road section & $1444-1599$ \\
3 & Satame road section & $1525-1991$ \\
4 & Koka road section & $1986-2160$ \\
5 & Lamo road section & $1877-2141$ \\
\hline
\end{tabular}

Apart from elevation and slope, vegetation cover/land use, rainfall, and soil type are also important factors for the formation of gully erosion. In the preliminary field visits the entire road sections were recognized to have similarity in terms of land use, rainfall and soil types. Therefore, elevation was taken as criteria for selecting the study road segments. Accordingly, three sections were purposely selected from the identified five sections to represent the entire road segment; namely, Ereramo (the lower elevation), Koka (the upper elevation) and Satame (the middle elevation). Of the total $32 \mathrm{kms}$ road the sampled road segments covered about 22 $\mathrm{kms}$, which means $69 \%$ of the total length of the road. Boundaries of gullies were set considering maximum length of the gully $(130 \mathrm{~m})$ on both sides of the road, which is perpendicular to the main road. This does not mean the longest gully is $130 \mathrm{~m}$, but the longest gully which ends with waterway or 
Road Construction and Gully Development in Hadero Tunto-Durgi................BELAYNEH et al.

ends with depositional area and perpendicular to the main road is $130 \mathrm{~m}$ long. Therefore, the study area covers 572 ha.

\section{Data Collection}

Data for gully erosion assessment were collected from field measurements in the selected road sections. Data collected include: Gully width, length and depth were measured in each selected gully site. To overcome inaccuracies of gully measurement that could have been created as a result of irregular shapes of gullies, each gully had been divided into different sections with similar shape - width and/or depth. In this regard, overall 307 sub sections identified and measurements made on them. In each section three measurements were taken and the average was used to represent the specific gully section. Since the final measurement of gully dimensions was to assess the amount of soil loss, soil bulk density was used to convert the volumetric soil estimates into soil mass (in terms of ton) for the given gully sections. The bulk density was determined from soil samples collected from nine locations that represent gully sections.

The perceptions of farmers were evaluated through interviewing selected households living along the study road segments. A total of 400 household heads living along the sampled road segments were listed. A questionnaire was administered for 103 households, $25 \%$ of the total household heads. This was done by considering every fourth household head that lives along the selected road segment. The questionnaire considered such issues as major causes of gully erosion, damages and associated problems surrounding the road, and the possible solutions for the problems.

\section{Data Analysis}

Correlation between volume of gully erosion as dependent variable and morphometric characteristics of gullies (i.e., width, depth and length) as independent variables were considered using stepwise method in SPSS version 20 statistical software to identify significant and useful index to estimate the volume of gully erosion. Sample household heads (farmers') responses were analyzed using descriptive statistical analysis techniques. The GPS readings were taken along the two sides of the road to map the gullies and show their distribution. This was done using Arc GIS 9.3 software.

\section{Results and Discussion Distribution of Gullies}

Distribution of gullies along the road of Hadero Tunto - Durgi is shown in Fig.2. As observed in the field, gullies are associated mainly with roadside ditch and /or culvert of the road. In the selected road segment 20 new gullies were developed immediately down slope of the road between the year 2008 and 2012 (Interview response, 2012). Of the total 20 gullies measured in the field, 13 were developed in relation to ditch construction, whereas 7 of them were developed in relation to culvert below the road; Figure 2 shows the distribution of inventoried gullies in the road sections of Ereramo, Satame, and Koka and these sections consisted $30 \%, 55 \%$, and $15 \%$ of gullies respectively. 


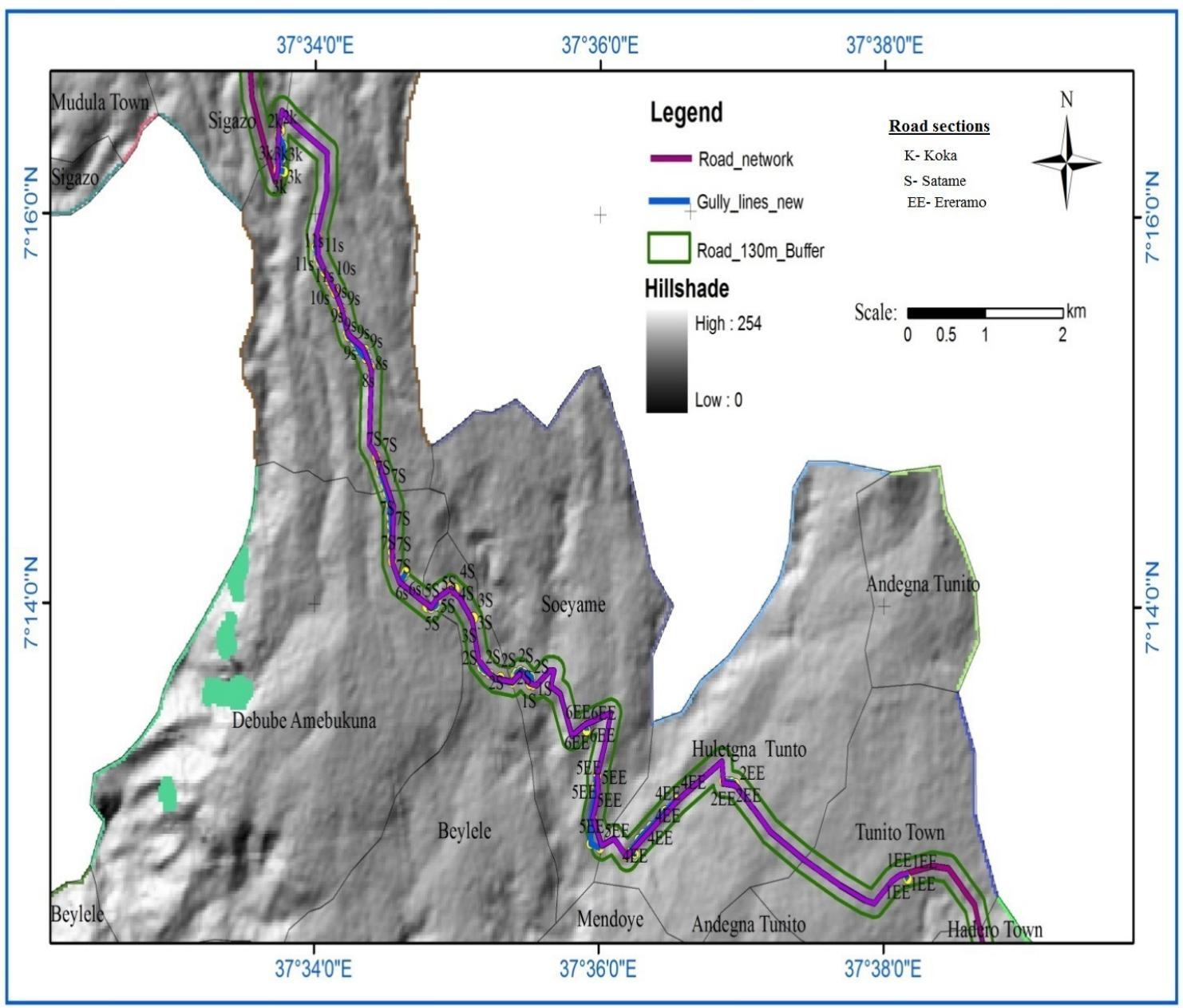

Figure 2: Distribution of gullies in the road segment (Numbers followed by letters in the figure indicate number of gullies and the road section measured)

Development of road side gullies have found associated with road construction in the sample site mainly due to the concentrated flow of runoff onto loose and unprotected soil. The concentration may be caused by either the coalescence of a series of rills or by collection of runoff in a depression, spatially by roadside drain and culvert by scouring (Figure 3). Field observation of most sensitive parts of the road (ditch and culvert) revealed that none of them were paved well to prevent soil erosion. This observation is in agreement with Mati's (1993) remark in which he argues that unpaved roads are more susceptible to erosion. Furthermore, according to farmers' explanations the rate of development of gully in terms of depth and width in the study area is higher for gullies developed due to culverts than that of roadside ditches. This study is in agreement with the study by Jungerius et al. (2002), in which water issuing from culverts is more concentrated and more turbulent and therefore more erosive than water in open drains. Furthermore, detailed discussions with residents of the study area revealed that steep slope cultivation and grazing, and increased run-off from land use changes such as tree clearing in the upper catchment were found to be additional triggering factors for gully erosion. 

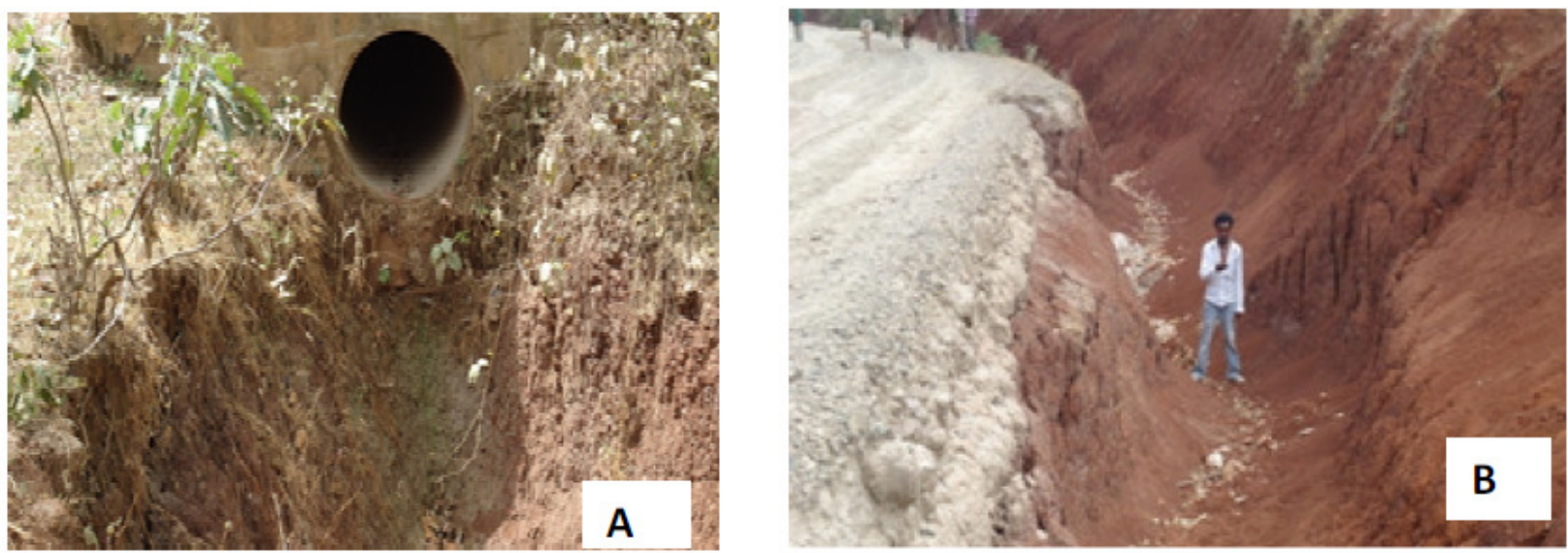

Figure 3: The gully associated with culvert (A) and the gully associated with roadside ditch (B)

Characteristics of Gully Erosion

Gullies developed due to culverts in the study area showed expansion in the forward direction along the lower slopes, expanded to the side, and deepened at the upper, middle and lower part. In such gullies there is no upward movement. When compared to the ditch gullies, culvert gullies are deep and wide. This result is similar with the findings of Solomon (2006). Deep erosion makes the gully bank unstable and causes movement of the earth from the sides of the gully to its bed, where the earth is removed by the intermittent water flows. In this way the gully is not only deepened, but also widened (Pathak et al., 2006). Gullies associated with roadside ditches expand like that of culverts and also have upward erosion. Dimensions of gullies due to ditches and culverts in the three selected road sections are presented in Table 2.

Table 2: Gully characteristics (dimensions) of each road section in the study area

\begin{tabular}{llllll}
\hline Gully characteristics & Ereramo & Satame & Koka & mean & St. deviation \\
\hline No. of gullies & 6 & 11 & 3 & - & - \\
No. of sub Sections of gullies & 80 & 192 & 35 & & \\
Ave. top width (m) & 2.17 & 2.72 & 3.24 & 2.71 & .54 \\
Av. bottom width (m) & .65 & 1.01 & 1.07 & .91 & .23 \\
Av. Width (m) & 1.41 & 1.86 & 2.16 & & \\
Ave. depth (m) & 2.50 & 2.15 & 3.67 & 2.77 & .80 \\
Total length (m) & 1419.12 & 4790.7 & 476.65 & & \\
Gully Surface area $\left(\mathrm{m}^{2}\right)$ & 2846.60 & 11617.4 & 1645.9 & & \\
Soil bulk density & 1.1 & 1.13 & 1.09 & & \\
(gm/cm $^{3}$ ) & & & & & \\
Soil loss (tone)* & $5,526.3$ & $29,273.7$ & $5,232.7$ & & \\
Density (m/ha) & 7.79 & 16.75 & 4.58 & 9.37 & 5.73 \\
Gully: Plot ratio** & .0016 & .0041 & .0016 & .0025 & .0015 \\
\hline
\end{tabular}

* Soil loss was calculated from values of each sub sections (measurements undertook on 307 sub sections from the identified 20 gullies), hence the product of average width, average depth and total length indicated here is a little different to the values calculated by considering each subsection

**Gully to plot area is a ratio of the sum of surface area $\left(\mathrm{m}^{2}\right)$ of all gullies of the given road section to the area (ha) of the corresponding road section 


\section{Gully Classification}

Gullies can be categorized into three classes based on gully lengths: namely, small $(<5 \mathrm{~m})$, medium (5- $10 \mathrm{~m}$ ) and large gullies (>10 m) (Pathak et al., 2006). Based on this classification scheme all measured gullies from the field are under the category of large gullies. Gullies using gully depth can be classified as: small gully with average depth of less than $1 \mathrm{~m}$, medium gully with average depth between 1-5 m, and large gully with average depth greater than $5 \mathrm{~m}$ (Pathak et al., 2006). The medium gullies were dominant over large and small gullies in all the road sections (Figure 4).

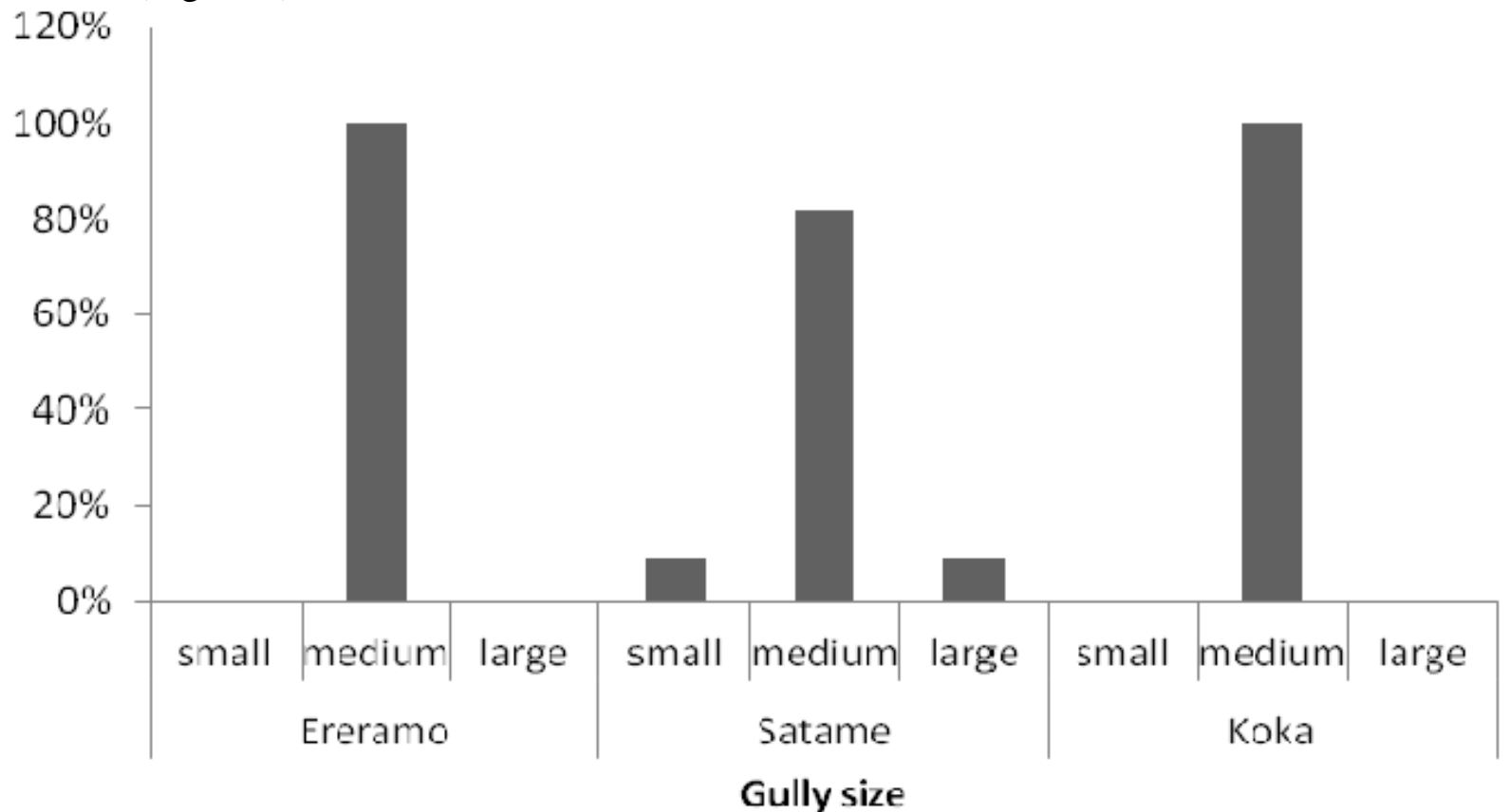

Figure 4: Gully classification based on depth in the study area

\section{Relationship among Major Gully Morphometric Parameters}

The correlation of gully morphology of the studied gullies (Table 3) shows that, there is a linear and positive relationship between gully width and gully depth; between width and soil loss; and gully depth and soil loss. These relations are significant at $1 \%$ significance level with $\mathrm{R}$ value of $0.83,0.73$ and 0.64 respectively. This result is similar with that of Solomon (2006), which shows that there is linear and positive correlation between gully width and depth although the correlation $\left(\mathrm{R}^{2}=0.26\right)$ is relatively lower. On the other hand this result contradicts with that of Alemu (2012).

Table 3: Correlation between gully characteristics $(\mathrm{N}=$ sub sections=307)

\begin{tabular}{lllll}
\hline & Av. Width & Length & Av. Depth & Soil loss \\
\hline Av.Width & 1 & -.02 & $.83^{*}$ & $.73^{*}$ \\
Length & 1 & -.10 & .26 \\
Av. Depth & & 1 & $.64^{*}$ \\
Soil loss & & & 1 \\
\cline { 2 - 5 } *. Correlation is significant at the .01 level (2-tailed). & &
\end{tabular}


Road Construction and Gully Development in Hadero Tunto-Durgi................BELAYNEH et al.

Results of statistical analysis as shown in table 3 below indicate that the volume of gully erosion had positive relationship with width and depth and no significant relationship with length. The soil loss by gully erosion had significant correlation with width and depth $(\mathrm{p}=.01)$. The linear equation existed between the soil loss of the studied gullies implies that the variation on soil loss is mainly because of the width and it would further better explained in combination with other parameters, i.e., depth and length (Table 3). Though width and depth are highly correlated, the calculated Variation Inflation Factor (VIF) in determining the collinearity in the regression is below five in all cases and therefore, the multiple regression equation with soil loss as dependent variable and width, length and depth of gullies as independent variables is shown in Table 4.

Table 4: Model parameters for estimating (inferring) volume of soil loss from gullies along the road side

\begin{tabular}{lllrll}
\hline & Constant & $\mathrm{b}_{1}$ & $\mathrm{~b}_{2}$ & $\mathrm{~b}_{3}$ & $\mathrm{R}^{2}$ \\
\hline W & -220.88 & 205.72 & & & .53 \\
W, L & -377.42 & 206.97 & 7.09 & & .60 \\
W,D,L & -395.87 & 156.9 & 40.01 & 7.6 & .61 \\
\hline
\end{tabular}

The associated linear models that would infer volume at different coefficients of determination are the following.

$$
\begin{array}{cc}
S=220.88+205.72 W & \left(\mathrm{R}^{2}=.53\right) \\
S=-377.42+206.97 W+7.09 L & \left(\mathrm{R}^{2}=.60\right) \\
S=-395.87+156 W+40.01 D+7.6 L & \left(\mathrm{R}^{2}=.61\right) \\
\text { Where: } \mathrm{S}=\text { soil loss (converted to ton) } & \\
\text { W }=\text { average width of a gully }(\mathrm{m}) & \\
\mathrm{D}=\text { average depth of a gully }(\mathrm{m}) & \\
\text { L }=\text { length of a gully }(\mathrm{m}) &
\end{array}
$$

From the above set of equations and table 3 , equation three is the best fit for explaining the relationship among gully parameters, though its difference in its coefficient of determination with equation two is quite small.

Damages and Associated Problems of the Gullies: Farmers Perceptions

Gullies formed and developed along the selected road segment have on- site and offsite effects. Specific on-site effects include: a reduction in the area of arable and other agricultural land, which divides the land into smaller parcels and leads to increased farming costs, restricts human and animal movement, reduces access to properties, and increases rates of erosion where more subsoil material is exposed. Study by Nyssen et al. (2002) shows that gullies developed during the first rainy season after road construction and kept growing destroy large tracts of arable land and preventing farmers moving from one part of their field to the other. Similar studies ([Billi and Dramis, 2003; Woldeamlak and Sterk, 2003) indicate that gully erosion is most prevalent type of water erosion in Ethiopia that dissects fields, impedes tillage operations, damages agriculture and residential places, and restricts free movement of animals and human beings. 
The off-site effects of gully erosion due to road construction in the study area were sedimentation and increased flooding which affect fences, farms, and public roadways in the downstream; sedimentation of waterways and water supplies; increased turbidity and nutrient loads in streams; and pollution of streams from agricultural chemicals and animal effluent in incised waterways. A study carried out in Western Hungary (Jake, 2009) indicated that about $50 \%$ of the total sediment in the catchment is being delivered by gully erosion. Additionally, interviewed farmers in the study area explained that crops growing close to the gullies usually dry up before reaching full maturity and they believed that wind blowing through the gully has the capacity to dry up their crops.

Of the total interviewed household heads $96 \%$ perceived the occurrence of gully erosion in their area and recognized it as a problem. They further believed that its severity has increased in the last five years. Regarding causes of gully erosion in the study area, majority of respondents $(85 \%)$ identified that road construction is the major cause of gully erosion. When we analyzed specific causes, interviewed households who associated the major causes of gullies to road culvert and ditches were $86 \%$, in relation to lack of ditch layering were $75 \%$, in relation to insufficient capacity of ditches and small number of culverts were $56 \%$ and in relation to cut and fill of slope during road construction were $47 \%$.

In general, it has been observed that gully developments are associated with construction of road with limited number of culverts, and construction of ditches and culvert without layering and without giving care to the land below the road. This induces surface runoff concentration, changes catchment sizes and shapes and diverts concentrated runoff to nearby catchments. The study by Nyssen et al. (2002) in northern
Ethiopian highlands shows that farmers observed important gully initiation on their lands just down slope of culverts and outlets of lateral road drains. The above researchers counted 16 new gullies developed along the studied $65 \mathrm{~km}$ long road segment after the building of the road in 1993 to early 1994.

The result of our study is also in agreement with several research findings (e.g., Moeyersons, 1991, 2000; Wemple et al., 1996) in which they reported that inadequate drainage systems of roads such as small number of culverts and insufficient capacity of road ditches are some of the causes of gulling.

Major problems identified by farmers due to gully erosion in the study area are loss of soil, obstruction of tillage operation, restriction of animals and human movement, taking away of materials by flooding during the rainy season, and change of the beauty of the environment.

The interviewed household heads reported that stone check dams, tree planting, cut off drains to divert excess water from upland and gabion check dams are the main gully erosion control measures in the study road segment. But, none of conservation measures mentioned above were implemented to rehabilitate gullies created due to the road. No one cares about the negative consequences in downstream and gully that is caused by and available close to public road which crosses the farm of the households. Furthermore, no one cares to mobilize residents to implement conservation tasks on such common land. Though, the benefit of gully rehabilitation is for the households who live along the road, they need incentives from local government body to undertake the conservation measures. Therefore, the local governmental body should be involved in the rehabilitation works of gully erosion developed in relation 
Road Construction and Gully Development in Hadero Tunto-Durgi................BELAYNEH et al.

to the road in collaboration to the local people.

\section{Conclusion and Recommendation}

This study assessed the impact of road construction on the formation and development of gullies, particularly along the Hadero Tunto-Durgi road that was built between 2006 and 2008 in Southern Ethiopia. The investigation revealed that a total of 20 gullies were formed after the road construction. Of the 20 gullies, 6 were found in Ereramo, 11 in Satame, and 3 in Koka road section. The main causes were improper construction of ditches with absence of layers and layering a few distances of the ditches and leaving even with steep slope without diverting the concentrated runoff to safe place, insufficient capacity of ditches and the construction of culverts without considering the land use below the culvert. The result of gully morphometry investigation reveals that, $2846 \mathrm{~m}^{2}$ area of land from Ereramo road section, $11617.4 \mathrm{~m}^{2}$ from Satame and $1646 \mathrm{~m}^{2}$ of land from Koka road section were damaged due to gully erosion that was caused by the road construction and a total of 44,150.4 tones of soil has been lost since gully initiation. The annual soil loss in the study area was 12.86 tons per hectare since 2006 and the total damaged area estimated at $16,109 \mathrm{~m}^{2}$. The gully density appeared 9.36 $\mathrm{m} / \mathrm{ha}$, which implies moderately to severely degraded situation.. The computed values of parameters of gullies indicate that there is a need for wise soil and water conservation planning that decreases the amount of soil loss and risks associated with gully.

Residents of the study area are very well aware of the impact of the road in relation to gully initiation and its further development. Specific on-site effects of gully erosion due to the road construction in the study area were: (a) reduction in the size of cultivated and other agricultural land, (b) division of the land into smaller parcels and leads to increased farming costs and increased rates of erosion where more subsoil material is exposed. The often mentioned offsite effects of gully erosion are also prevailing in the study area. They include: (a) destruction of fences, farms and public roadways in the downstream by the gully-flood, (b) sedimentation of waterways and water supplies, (c) increased turbidity and nutrient loads in streams and pollution from agricultural chemicals and animal effluent in incised waterways. In addition, residents are worried about gully associated risks of children and animals falling into the gully, increased distance to travel from the village and the associated burden to women are other problems. Therefore, the above findings call for road construction contractors to think of ways to direct concentrated runoff from roadsides to the nearby natural channel without causing damages to the farmer's livelihood and the environment.

\section{Acknowledgment}

We thank the NORAD project for financial support of this study. Numerous farmers and experts helped during the data collection; among them we are especially thankful to Mr. Zeleke Belayneh, Mr. Habtamu Dawit, Mr. Adissu Belayneh, Mr. Alemu Osore, and Mr. Robel Hailemichael for their contribution of gully measurement and motivation. We also thank the anonymous reviewers.

\section{References}

Alemu Osore (2012). Extent of Gully Erosion and Farmer's Perception on Soil Erosion: A Case Study in Alalicha Micro - Watershed, Dale Woreda, Southern Ethiopia. MSc Thesis, Submitted to the Institute of Technology, School of Biosystems and 
Environmental Engineering, Hawassa University, Hawassa

Billi, P. and Dramis, F. (2003). Geomorphological investigation on gully erosion in the Rift Valley and the northern highland of Ethiopia. Catena, 50: 353-368.

BoFED (Bureau of Finance and Economic Development, SNNPR). 2004. Regional atlas. Southern Nation, Nationalist People Regional State, Bureau of Finance and Economics Development, Hawassa, Ethiopia

Jake, B.G. (2009). The Influence of Environmental conditions on gully development: $\mathrm{PhD}$ Thesis. Manuscript. Budapest,: Geoqr. Res. inst. H.A.S. ELTE

Jungerius, J., Matundura, J.A. and Vande, A. (2002). Road Construction and Gully Erosion in West Pokot, Earth Surf; Process: Landforms, 27: 1237-1247.

Mati, B.M. (1993). Soil erosion and conservation activities on land affected by road drainage: a case study of Nyeri District. In Workshop Abstracts, 4th Land and Water Management Workshop towards Sustainable Land Use; University of Nairobi. Limited; England 350pp

Mesfin Abebe (1998). Nature and Management of Ethiopian Soils. Alemaya: Alemaya University of Agriculture (Ethiopia)

Moeyersons, J. (1991). Ravine formation on steep slopes: forward versus regressive erosion. Some case studies from Rwanda. Catena 18(3): 309-324

Moeyersons, J. (2000). Desertification and Man in Africa: Bulletin of the Royal Academy of Overseas Science, Brussels, 46:151-170

Montgomery D. (1994). Road surface drainage, channel initiation, and slope instability. Water Resources Research, 30(6): 1925-1932.
Nyssen, J., Poesen, J., Moeyersons, J., Luyten, E., Veyret-Picot, M. and Deckers, J.G. (2002). Impact of Road Building on Gully Erosion Risk: A Case study from the Northern Ethiopian Highlands. Earth Surf. Process Landforms, 27: 1267-1283

Ogbaghebriel, B. and Brancaccio, L. (1993). Some reflections on the origin and land use of pediments on Ethiopian Highlands; Geografia Fisica eDinamica del Quaternario. 16: 101-106.

Pathak, P, Wani, S.P. and Sudi, R. (2006). Gully control in SAT watersheds. An Open Access Journal, SAT Journal Volume 2: published by ICRISAT, Andhra Pradesh, India. AT (http://www.icrisat.org/journal/agroecos ystem/v2i1/v2i1gully.pdf)(Accessed on 10 January 2013)

Peter, H, Cafferata and John, R.M. (2002). Hillslope monitoring program. California : California Department of Forestry and Fire Protection

Solomon Addisu. (2006). Assessment of the Impact of Road Construction on Physical Land Degradation: Central Highlands of Ethiopia. MSc Thesis in Environmental Science Programme, Addis Ababa University, Ethiopia

Wemple, B.C., Jones, J.A. and Grant, G.E. (1996). Channel Network Extension by Logging Roads in two Basins, Western Cascades. Water Resources Bulletin, 32 (6): 1195- 1207.

Woldeamlak Bewket and Sterk G. (2003). Assessment of soil erosion in cultivated fields using a survey methodology for rills in the Chemoga watershed, Ethiopia: Agriculture, Ecosystems and Environment, 97 (1-3): 81 - 93.

World Bank. (1994). World Development Report 1994: Infrastructure for Development. Oxford: Oxford University Press 